medRxiv preprint doi: https://doi.org/10.1101/2021.08.19.21262292; this version posted August 22, 2021. The copyright holder for this preprint (which was not certified by peer review) is the author/funder, who has granted medRxiv a license to display the preprint in perpetuity.

All rights reserved. No reuse allowed without permission.

\title{
Seroresponse to SARS-CoV-2 vaccines among maintenance dialysis patients
}

Authors: Caroline M. Hsu ${ }^{1}$, Daniel E. Weiner ${ }^{1}$, Gideon N. Aweh ${ }^{2}$, Harold J. Manley ${ }^{2}$, Vladimir Ladik ${ }^{2}$, Jill Frament ${ }^{2}$, Dana Miskulin ${ }^{1}$, Christos Agyropoulos ${ }^{3}$, Kenneth Abreo ${ }^{4}$, Andrew Chin ${ }^{5}$, Reginald Gladish ${ }^{6}$, Loay Salman ${ }^{7}$, Doug Johnson ${ }^{2}$, Eduardo K. Lacson ${ }^{1,2}$

1. Tufts Medical Center, Boston, MA

2. Dialysis Clinic Inc., Nashville, TN

3. University of New Mexico, Albuquerque, NM

4. Louisiana State University Health Sciences Center, Shreveport, LA

5. University of California Davis, CA

6. Nephrology of North Alabama, Decatur, AL

7. Albany Medical College, Albany, NY

\section{Address for Correspondence:}

Caroline M. Hsu

800 Washington St, Box \#391

Boston, MA 02111

chsu1@tuftsmedicalcenter.org

Support: This report was supported by Dialysis Clinic, Inc. CMH receives support from ASN KidneyCure's Ben J. Lipps Research fellowship. CMH's funder had no role in study design, data collection, reporting, or the decision to submit.

Financial Disclosure: Mr. Aweh, Dr. Manley, Mr. Ladik, Ms. Frament, Dr. Johnson and Dr. Lacson Jr are all employees of DCl, where Dr. Johnson is Vice Chair of the Board. Dr. Weiner, Dr. Miskulin, Dr.

Agyropoulos, Dr. Abreo, Dr. Chin, Dr. Gladish, and Dr. Salman receive salary support to their institution from $\mathrm{DCl}$. 
medRxiv preprint doi: https://doi.org/10.1101/2021.08.19.21262292; this version posted August 22, 2021. The copyright holder for this preprint (which was not certified by peer review) is the author/funder, who has granted medRxiv a license to display the preprint in perpetuity.

All rights reserved. No reuse allowed without permission.

\begin{abstract}
Importance: Vaccines against SARS-CoV-2 are highly effective in the general population; however, their efficacy may be diminished in maintenance dialysis patients, a population particularly vulnerable to COVID-19 infection and morbidity.
\end{abstract}

Objective: We assessed vaccine response in a national sample of maintenance dialysis patients and identified predictors of response.

Design: Retrospective cohort study

Setting: 130 Dialysis Clinic, Inc (DCl) facilities

Participants: Maintenance dialysis patients without known prior COVID-19 or a positive baseline antibody titer

Exposure(s): Vaccine type and clinical characteristics

Main Outcome(s): Using a semi-quantitative assay for antibodies against SARS-CoV-2 spike antigen, vaccine response was defined as at least one titer $\geq 1 \mathrm{U} / \mathrm{L}$ between 14 and 74 days after completion of a SARS-CoV-2 vaccine series. Regression analysis was used to identify characteristics associated with response.

Results: Among 1528 patients, 437 received BNT162b2/Pfizer vaccine, 766 received mRNA1273/Moderna, and 325 received Ad26.COV2.S/Janssen. Serologic response differed significantly by vaccine type: 381/437 (87\%) among BNT162b2/Pfizer recipients, 736/766 (96\%) among mRNA1273/Moderna recipients, and 119/325 (37\%) among Ad26.COV2.S/Janssen recipients. Vaccine type, older age, immune-modulating medication, history of transplantation, and lower serum albumin were associated with vaccine non-response.

Conclusions and Relevance: Serologic response to mRNA vaccines is robust among maintenance dialysis patients. Future research should evaluate durability of this response, correlation between seroresponse and protection from COVID-19, and the role of the AD26.COV2.S/Janssen vaccine in this vulnerable population. 
medRxiv preprint doi: https://doi.org/10.1101/2021.08.19.21262292; this version posted August 22, 2021. The copyright holder for this preprint (which was not certified by peer review) is the author/funder, who has granted medRxiv a license to display the preprint in perpetuity.

All rights reserved. No reuse allowed without permission.

\section{Introduction}

As of August 2021, three vaccines against SARS-CoV-2 have received Emergency Use Authorization (EUA) by the United States Food and Drug Administration (FDA): two mRNA vaccines (BNT162b2/Pfizer and mRNA-1273/Moderna) and one adenoviral vector vaccine (Ad26.COV2.S/Janssen). All three vaccines are highly effective in the general population, ${ }^{1-3}$ and their widespread deployment has shifted the course of the COVID-19 pandemic.

Studies to date suggest a high seroresponse rate (greater than $80 \%$ ) to mRNA vaccines in maintenance dialysis patients, albeit less than that in the general population. ${ }^{4-7} \mathrm{~A}$ report in 76 dialysis patients that Ad26.COV2S elicits lower seroresponse warrants further study; ${ }^{8}$ moreover, small sample sizes have so far limited evaluation of predictors of non-response. Accordingly, we retrospectively analyzed seroresponse to SARS-CoV-2 vaccines in maintenance dialysis patients, updating an earlier report. ${ }^{9}$

\section{Methods}

Dialysis Clinic, Inc. (DCI) is a national not-for-profit provider that cares for more than 15,000 patients at 260 outpatient dialysis clinics across 29 states. Beginning in January 2021, DCl physicians had the option of activating a SARS-CoV-2 vaccine protocol, modeled after the existing hepatitis B vaccine protocol whereby antibody titers are measured to document seroresponse to vaccination. Treating physicians could activate the protocol upon patient receipt of SARS-CoV-2 vaccine, regardless of vaccine type or site of administration. As part of the monthly blood draws beginning after receipt of a SARS-CoV-2 vaccine, immunoglobulin $\mathrm{G}$ spike antibodies (SAb-lgG) against the receptor-binding domain of the $\mathrm{S} 1$ subunit of SARS-CoV-2 spike antigen were measured using the chemiluminescent assay ADVIA Centaur ${ }^{\circledR}$ XP/XPT COV2G, which received emergency use authorization in July $2020 .^{10}$ This semi-quantitative assay has a range between 0 and $\geq 20 \mathrm{U} / \mathrm{L}$, and SAb-lgG titer $\geq 1 \mathrm{U} / \mathrm{L}$ signifies patient seroresponse. ${ }^{10}$ 
medRxiv preprint doi: https://doi.org/10.1101/2021.08.19.21262292; this version posted August 22, 2021. The copyright holder for this preprint (which was not certified by peer review) is the author/funder, who has granted medRxiv a license to display the preprint in perpetuity.

All rights reserved. No reuse allowed without permission.

Demographic and clinical data, vaccination dates, and SAb-IgG titer results were obtained from the DCI electronic health record. Patients with previously diagnosed COVID-19 were excluded, as were patients with SAb-IgG titer $\geq 1 \mathrm{U} / \mathrm{L}$ before vaccination or within 10 days after vaccination for likely prior undiagnosed COVID-19.

In primary analyses, we determined the SARS-CoV-2 vaccine seroresponse rates at 14 to 74 days after completion of a vaccine series, as well as time to peak titer within this time frame. This timing of SAbIgG titer assessment (at least 14 days after completion of vaccine series) corresponds with the currently accepted definition of "fully vaccinated." ${ }^{11}$ Multivariable log Poisson regression with robust variances was used to analyze the association of demographic and clinical factors with vaccine seroresponse. Secondary analyses used alternate definitions of vaccine seroresponse: (1) utilizing SAb-lgG $\geq 2 \mathrm{U} / \mathrm{L}$ (a threshold suggested by DCl's internal validation methods), and (2) utilizing the first SAb-lgG titer measured at least 14 days after completion of a vaccine series. This study was reviewed and approved by the WCG IRB Work Order 1-1456342-1. Statistical analyses were performed using SAS v9.4.

\section{Results}

Between February 1 and July 6, 2021, 1528 patients (437 [29\%] BNT162b2/Pfizer recipients, 766 [50\%] mRNA-1273/Moderna recipients, and 325 [21\%] Ad26.COV2.S/Janssen recipients) across 130 dialysis facilities had SAb-IgG titers measured after receiving SARS-CoV-2 vaccination. 1029 (67\%) patients had more than one titer checked between 14 and 74 days after completion of the vaccine series. Patients who received BNT162b2/Pfizer tended to be older, likely reflecting its earlier EUA and rollout. (Table) 
medRxiv preprint doi: https://doi.org/10.1101/2021.08.19.21262292; this version posted August 22, 2021. The copyright holder for this preprint (which was not certified by peer review) is the author/funder, who has granted medRxiv a license to display the preprint in perpetuity.

All rights reserved. No reuse allowed without permission.

Vaccine seroresponse varied significantly by vaccine received: 381/437 (87\%) of BNT162b2/Pfizer recipients, 736/766 (96\%) of mRNA-1273/Moderna recipients, and 119/325 (37\%) of

Ad26.COV2.S/Janssen recipients. Median [interquartile range] number of days to peak titer from completion of the vaccine series was 33 [20-42], 29 [19-40], and 47 [34-61] days for the 3 vaccines, respectively. At titer $\geq 2 \mathrm{U} / \mathrm{L}$, response rate was slightly lower for all vaccine types, with the greatest difference occurring in Ad26.COV2.S/Janssen recipients. When utilizing first SAb-IgG titer at least 14 days after completion of a vaccine series, seroresponse rate was significantly lower only among Ad26.COV2.S/Janssen recipients. (Supplemental Table).

In multivariable analysis, vaccine type, older age, non-Black and non-Native American race, immunemodulating medications, history of transplantation, and lower serum albumin were associated with lower likelihood of vaccine seroresponse (Figure).

\section{Discussion}

Among maintenance dialysis patients, mRNA vaccines against SARS-CoV-2 elicited appropriate seroresponse in the vast majority, consistent with prior reports of mRNA vaccines worldwide. ${ }^{4-7}$ In contrast, seroresponse to the Ad26.COV2.S/Janssen vaccine was low, consistent with an earlier small study, ${ }^{8}$ and suggesting that mRNA-based SARS-CoV-2 vaccines should be recommended for maintenance dialysis patients, particularly given their high morbidity and mortality from COVID-19. ${ }^{12}$

The comparatively low seroresponse rate to the Ad26.COV2.S/Janssen vaccine among the dialysis population is concerning. SAb-IgG antibodies are thought to confer protection from COVID-19 itself via neutralization of the spike protein, and post-vaccination antibody titers have been shown to correlate with protection from COVID-19. ${ }^{13}$ As an adenoviral vector vaccine, the Ad26.COV2.S/Janssen vaccine 
medRxiv preprint doi: https://doi.org/10.1101/2021.08.19.21262292; this version posted August 22, 2021. The copyright holder for this preprint (which was not certified by peer review) is the author/funder, who has granted medRxiv a license to display the preprint in perpetuity.

All rights reserved. No reuse allowed without permission.

must enter the cell nucleus and undergo transcription, an extra step compared to mRNA vaccines. Of note, the timing of SAb-lgG titer assessment may have affected results; as a single-dose regimen, the response to Ad26.COV2.S here is assessed 3-4 weeks earlier relative to the initial vaccine dose than is the response to mRNA vaccines. The greater seroresponse by titer within 74 days versus by first titer suggests that the Ad26.COV2.S/Janssen vaccine's seroresponse may continue to increase beyond two weeks post-vaccination. However, long-term data from the phase 1-2a trial indicate that titers eventually level off and even decrease slightly. ${ }^{14}$ Thus, even allowing for later increase in seroresponse, the Ad25.COV2.SS/Janssen vaccine appears to have significantly lower efficacy than the mRNA vaccines among maintenance dialysis patients.

While only Ad26.COV2.S/Janssen's single low-dose regimen currently has emergency use authorization in the United States, the phase 1-2a trial had included two-dose regimens and high-dose regimens which elicited higher titers, albeit with more adverse events. ${ }^{15}$ Whether a second dose may provide benefit to certain populations remains under investigation (ClinicalTrials.gov number NCT04614948). The difference between BNT162b2/Pfizer and mRNA-1273/Moderna was less extreme but still statistically significant and may be related to differences of dosage (100 $\mu \mathrm{g}$ vs $30 \mu \mathrm{g}$ of mRNA content, respectively), or, given the earlier availability of the BNT162b2/Pfizer vaccine, unaccounted-for confounding factors. Admittedly, the SAb-IgG antibody titer needed for protection from COVID-19 and the role of vaccineinduced cellular immunity remain uncertain, issues that are also complicated by emerging variants.

Other than vaccine type, predictors of vaccine non-response were largely factors related to potential immunocompromise, including increasing age, the presence of immune-modulating medication, and lower serum albumin, all of which have been noted by others. ${ }^{4-6}$ 
medRxiv preprint doi: https://doi.org/10.1101/2021.08.19.21262292; this version posted August 22, 2021. The copyright holder for this preprint (which was not certified by peer review) is the author/funder, who has granted medRxiv a license to display the preprint in perpetuity.

All rights reserved. No reuse allowed without permission.

Our study has its limitations. In this observational retrospective study, some confounders may not have been accounted for. The comparison of maximum to initial SAb-IgG titers is limited by the patients who only had one titer checked between 14 and 74 days. Lastly, as noted, while the assessment of SAb-lgG titer at least 14 days after completion of vaccine series corresponds with the current definition of "fully vaccinated, ${ }^{11}$ it creates a difference in timing relative to the initial dose between one-dose and twodose regimens.

In conclusion, mRNA vaccines are associated with greater seroresponse in maintenance dialysis patients, and they should continue to be widely used to protect this vulnerable population. Further study is needed to monitor the durability of this seroresponse. In addition, further investigation should evaluate the role of the Ad26.COV2.S/Janssen vaccine in this population, and repeat dosing may be needed. 
medRxiv preprint doi: https://doi.org/10.1101/2021.08.19.21262292; this version posted August 22, 2021. The copyright holder for this preprint (which was not certified by peer review) is the author/funder, who has granted medRxiv a license to display the preprint in perpetuity. All rights reserved. No reuse allowed without permission.

\section{References}

1. Polack FP, Thomas SJ, Kitchin N, et al. Safety and Efficacy of the BNT162b2 mRNA Covid-19 Vaccine. N Engl J Med. 2020;383(27):2603-2615. doi:10.1056/NEJMoa2034577

2. Baden LR, El Sahly HM, Essink B, et al. Efficacy and Safety of the mRNA-1273 SARS-CoV-2 Vaccine. $N$ Engl J Med. 2021;384(5):403-416. doi:10.1056/NEJMoa2035389

3. Sadoff J, Gray G, Vandebosch A, et al. Safety and Efficacy of Single-Dose Ad26.COV2.S Vaccine against Covid-19. N Engl J Med. 2021;384(23):2187-2201. doi:10.1056/NEJMoa2101544

4. Anand S, Montez-Rath M, Han J, et al. Antibody Response to COVID-19 Vaccination in Patients Receiving Dialysis. J Am Soc Nephrol. Published online June 11, 2021. doi:10.1681/ASN.2021050611

5. Agur T, Ben-Dor N, Goldman S, et al. Antibody response to mRNA SARS-CoV-2 vaccine among dialysis patients - a prospectivecohort study. Nephrol Dial Transplant. Published online April 11, 2021. doi:10.1093/ndt/gfab155

6. Longlune $\mathrm{N}$, Nogier MB, Miedougé $\mathrm{M}$, et al. High immunogenicity of a messenger RNA based vaccine against SARS-CoV-2 in chronic dialysis patients. Nephrol Dial Transplant. Published online May 31, 2021. doi:10.1093/ndt/gfab193

7. Chan L, Fuca N, Zeldis E, Campbell KN, Shaikh A. Antibody Response to mRNA-1273 SARS-CoV-2 Vaccine in Hemodialysis Patients with and without Prior COVID-19. CJASN. Published online May 24, 2021:CJN.04080321. doi:10.2215/CJN.04080321

8. Mulhern J, Fadia A, Patel R, et al. Humoral Response to mRNA versus an Adenovirus Vector-Based SARS-COV2 (Ad26.COV2.S) Vaccine in Dialysis Patients. CJASN. Published online July 26, 2021:CJN.06450521. doi:10.2215/CJN.06450521

9. Lacson E, Argyropoulos CP, Manley HJ, et al. Immunogenicity of SARS-CoV-2 Vaccine in Dialysis. JASN. Published online August 4, 2021. doi:10.1681/ASN.2021040432

10. COV2G, ADVIA Centaur XP and ADVIA Centaur CPT Systems. Published online July 2020. Accessed June 22, 2021. https://www.fda.gov/media/140704/download

11. COVID-19: When You've Been Fully Vaccinated. Centers for Disease Control and Prevention; 2021. https://www.cdc.gov/coronavirus/2019-ncov/vaccines/fully-vaccinated.html

12. Hsu CM, Weiner DE, Aweh G, Salenger P, Johnson DS, Lacson E. Epidemiology and Outcomes of COVID-19 in Home Dialysis Patients Compared with In-Center Dialysis Patients. J Am Soc Nephrol. 2021;32(7):1569-1573. doi:10.1681/ASN.2020111653

13. Earle KA, Ambrosino DM, Fiore-Gartland A, et al. Evidence for antibody as a protective correlate for COVID-19 vaccines. Vaccine. 2021;39(32):4423-4428. doi:10.1016/j.vaccine.2021.05.063

14. Barouch DH, Stephenson K, Sadoff J, et al. Durable Humoral and Cellular Immune Responses Following Ad26.COV2.S Vaccination for COVID-19. Infectious Diseases (except HIV/AIDS); 2021. doi:10.1101/2021.07.05.21259918 
medRxiv preprint doi: https://doi.org/10.1101/2021.08.19.21262292; this version posted August 22, 2021. The copyright holder for this preprint (which was not certified by peer review) is the author/funder, who has granted medRxiv a license to display the preprint in perpetuity.

All rights reserved. No reuse allowed without permission.

15. Sadoff J, Le Gars M, Shukarev G, et al. Interim Results of a Phase 1-2a Trial of Ad26.COV2.S Covid-19 Vaccine. N Engl J Med. 2021;384(19):1824-1835. doi:10.1056/NEJMoa2034201 
medRxiv preprint doi: https://doi.org/10.1101/2021.08.19.21262292; this version posted August 22, 2021. The copyright holder for this preprint (which was not certified by peer review) is the author/funder, who has granted medRxiv a license to display the preprint in perpetuity.

All rights reserved. No reuse allowed without permission.

Figure. Multivariable regression of clinical characteristics predicting SARS-CoV-2 vaccine response

SARS-CoV-2 vaccine response defined as immunoglobulin-G spike antibodies ( $S A b-l g G$ ) against the receptor-binding domain of the S1 subunit of SARS-CoV-2 spike antigen titer $\geq 1 \mathrm{U} / \mathrm{L}$ measured 14-74 days after completion of a vaccine series

Hepatitis B seroimmunity defined as hepatitis B surface antibody $\geq 10 \mathrm{mlU} / \mathrm{mL}$

COPD Chronic Obstructive Pulmonary Disease

Analysis was performed with multivariable log Poisson regression with robust variances. 
medRxiv preprint doi: https://doi.org/10.1101/2021.08.19.21262292; this version posted August 22, 2021. The copyright holder for this preprint (which was not certified by peer review) is the author/funder, who has granted medRxiv a license to display the preprint in perpetuity. All rights reserved. No reuse allowed without permission.

Table. Patient characteristics by vaccine administered

\begin{tabular}{|c|c|c|c|c|c|}
\hline Demographics & $\begin{array}{l}\text { All Patients } \\
(\mathrm{N}=1,528)\end{array}$ & $\begin{array}{c}\text { BNT162b2/Pfizer } \\
(\mathrm{N}=437)\end{array}$ & $\begin{array}{c}\text { mRNA-1273/Moderna } \\
(\mathrm{N}=766)\end{array}$ & $\begin{array}{l}\text { Ad26.COV2.S/Janssen } \\
(\mathrm{N}=325)\end{array}$ & $\begin{array}{c}\text { P- } \\
\text { value }\end{array}$ \\
\hline Age (years) & $64.2 \pm 13.5$ & $66.8 \pm 12.9$ & $64.0 \pm 13.9$ & $61.3 \pm 12.6$ & $<0.001$ \\
\hline Female & $646(42.3)$ & $191(43.7)$ & $308(40.2)$ & $147(45.2)$ & 0.24 \\
\hline Race & & & & & $<0.001$ \\
\hline White & $768(50.3)$ & $198(45.3)$ & $447(58.4)$ & $123(37.8)$ & \\
\hline Black & $356(23.3)$ & $80(18.3)$ & $116(15.1)$ & $160(49.2)$ & \\
\hline Native American & $126(8.3)$ & $61(14.0)$ & $60(7.8)$ & $5(1.5)$ & \\
\hline Asian/Pacific Islander & $93(6.1)$ & $49(11.2)$ & $37(4.8)$ & $7(2.2)$ & \\
\hline Other/Unknown & $185(12.1)$ & $49(11.2)$ & $106(13.8)$ & $30(9.2)$ & \\
\hline Hispanic & $205(13.4)$ & $63(14.4)$ & $134(17.5)$ & $8(2.5)$ & $<0.001$ \\
\hline Vintage (months) & $53.0 \pm 58.1$ & $50.9 \pm 57.6$ & $52.4 \pm 57.0$ & $57.4 \pm 61.2$ & 0.28 \\
\hline Body Mass Index $\left(\mathrm{kg} / \mathrm{m}^{2}\right)$ & $28.4 \pm 7.1$ & $28.4 \pm 7.4$ & $28.1 \pm 6.4$ & $29.2 \pm 8.0$ & 0.06 \\
\hline Long Term Care Facility & 139(9.1) & 41(9.4) & 69(9.0) & $29(8.9)$ & 0.97 \\
\hline Home Dialysis & $224(14.7)$ & $59(13.5)$ & $130(17.0)$ & $35(10.8)$ & 0.02 \\
\hline Peritoneal Dialysis & 198(13.0) & $50(11.4)$ & $113(14.8)$ & $35(10.8)$ & \\
\hline Home Hemodialysis & $26(1.7)$ & $9(2.1)$ & $17(2.2)$ & $0(0.0)$ & \\
\hline Adequate Dialysis Dose $^{a}$ & $1,205(78.9)$ & $350(80.1)$ & $597(77.9)$ & $258(79.4)$ & 0.66 \\
\hline Serum Albumin $(\mathrm{g} / \mathrm{dl})$ & $3.9 \pm 0.4$ & $3.9 \pm 0.4$ & $3.9 \pm 0.4$ & $3.8 \pm 0.4$ & 0.05 \\
\hline $\begin{array}{l}\text { Other Vaccines within } 14 \\
\text { days }\end{array}$ & $129(8.4)$ & $40(9.2)$ & $62(8.1)$ & $27(8.3)$ & 0.81 \\
\hline Pneumococcal & $32(2.1)$ & $5(1.1)$ & $21(2.7)$ & $6(1.9)$ & 0.18 \\
\hline Hepatitis B & $101(6.6)$ & $35(8.0)$ & $44(5.7)$ & $22(6.8)$ & 0.31 \\
\hline Flu Vaccine & $6(0.4)$ & $2(0.5)$ & $4(0.5)$ & $0(0.0)$ & 0.99 \\
\hline Hepatitis B seroimmunity $^{b}$ & $1,099(71.9)$ & $317(72.5)$ & $557(72.7)$ & $225(69.2)$ & 0.34 \\
\hline $\begin{array}{l}\text { Potential } \\
\text { Immunosuppression }\end{array}$ & $276(18.1)$ & $94(21.5)$ & $126(16.5)$ & $56(17.2)$ & 0.08 \\
\hline $\begin{array}{l}\text { Immune-modulating } \\
\text { Medications }\end{array}$ & 197(12.9) & 69(15.8) & 91(11.9) & $37(11.4)$ & 0.10 \\
\hline Prior Transplant & $102(6.7)$ & $32(7.3)$ & $53(6.9)$ & $17(5.2)$ & 0.49 \\
\hline Immunodeficiency Disorder & $71(4.7)$ & $23(5.3)$ & $31(4.1)$ & $17(5.2)$ & 0.54 \\
\hline $\begin{array}{l}\text { Hospitalization within } 14 \\
\text { days }\end{array}$ & $194(12.7)$ & $58(13.3)$ & $103(13.5)$ & $33(10.2)$ & 0.30 \\
\hline Disability & $62(4.1)$ & $16(3.7)$ & $30(3.9)$ & 16(4.9) & 0.66 \\
\hline Tobacco Use & $205(13.4)$ & $48(11.0)$ & $101(13.2)$ & $56(17.2)$ & 0.04 \\
\hline Alcohol Abuse Disorder & $143(9.4)$ & $38(8.7)$ & 71(9.3) & $34(10.5)$ & 0.71 \\
\hline Drug Abuse Disorder & $51(3.3)$ & $14(3.2)$ & $27(3.5)$ & $10(3.1)$ & 0.92 \\
\hline Number of Comorbidities & $2.9 \pm 1.7$ & $2.9 \pm 1.6$ & $2.9 \pm 1.6$ & $3.1 \pm 1.8$ & 0.10 \\
\hline Diabetes Mellitus & $909(59.5)$ & $269(61.6)$ & $437(57.1)$ & $203(62.5)$ & 0.15 \\
\hline Hypertension & $1,310(85.7)$ & $371(84.9)$ & $657(85.8)$ & $282(86.8)$ & 0.77 \\
\hline Congestive Heart Failure & $298(19.5)$ & $72(16.5)$ & $150(19.6)$ & $76(23.4)$ & 0.06 \\
\hline COPD $^{c}$ & $230(15.1)$ & $65(14.9)$ & $100(13.1)$ & $65(20.0)$ & 0.01 \\
\hline $\begin{array}{c}\text { Stroke/Cerebrovascular } \\
\text { Disorder }\end{array}$ & $114(7.5)$ & $33(7.6)$ & $51(6.7)$ & $30(9.2)$ & 0.34 \\
\hline Peripheral Vascular Disease & $178(11.7)$ & $43(9.8)$ & $78(10.2)$ & $57(17.5)$ & 0.001 \\
\hline Thyroid Disorder & $248(16.2)$ & $64(14.7)$ & $136(17.8)$ & $48(14.8)$ & 0.27 \\
\hline History of Cancer & $136(8.9)$ & $41(9.4)$ & $74(9.7)$ & $21(6.5)$ & 0.22 \\
\hline
\end{tabular}

${ }^{\mathrm{a}}$ Adequate dialysis defined by hemodialysis single pool $\mathrm{Kt} / \mathrm{V} \geq 1.2$ or peritoneal dialysis weekly $\mathrm{Kt} / \mathrm{V} \geq 1.7$.

${ }^{\mathrm{b}}$ Hepatitis B seroimmunity defined as hepatitis B surface antibody $\geq 10 \mathrm{mIU} / \mathrm{mL}$

${ }^{c}$ COPD Chronic Obstructive Pulmonary Disease 
medRxiv preprint doi: https://doi.org/10.1101/2021.08.19.21262292; this version posted August 22, 2021. The copyright holder for this preprint (which was not certified by peer review) is the author/funder, who has granted medRxiv a license to display the preprint in perpetuity. All rights reserved. No reuse allowed without permission.

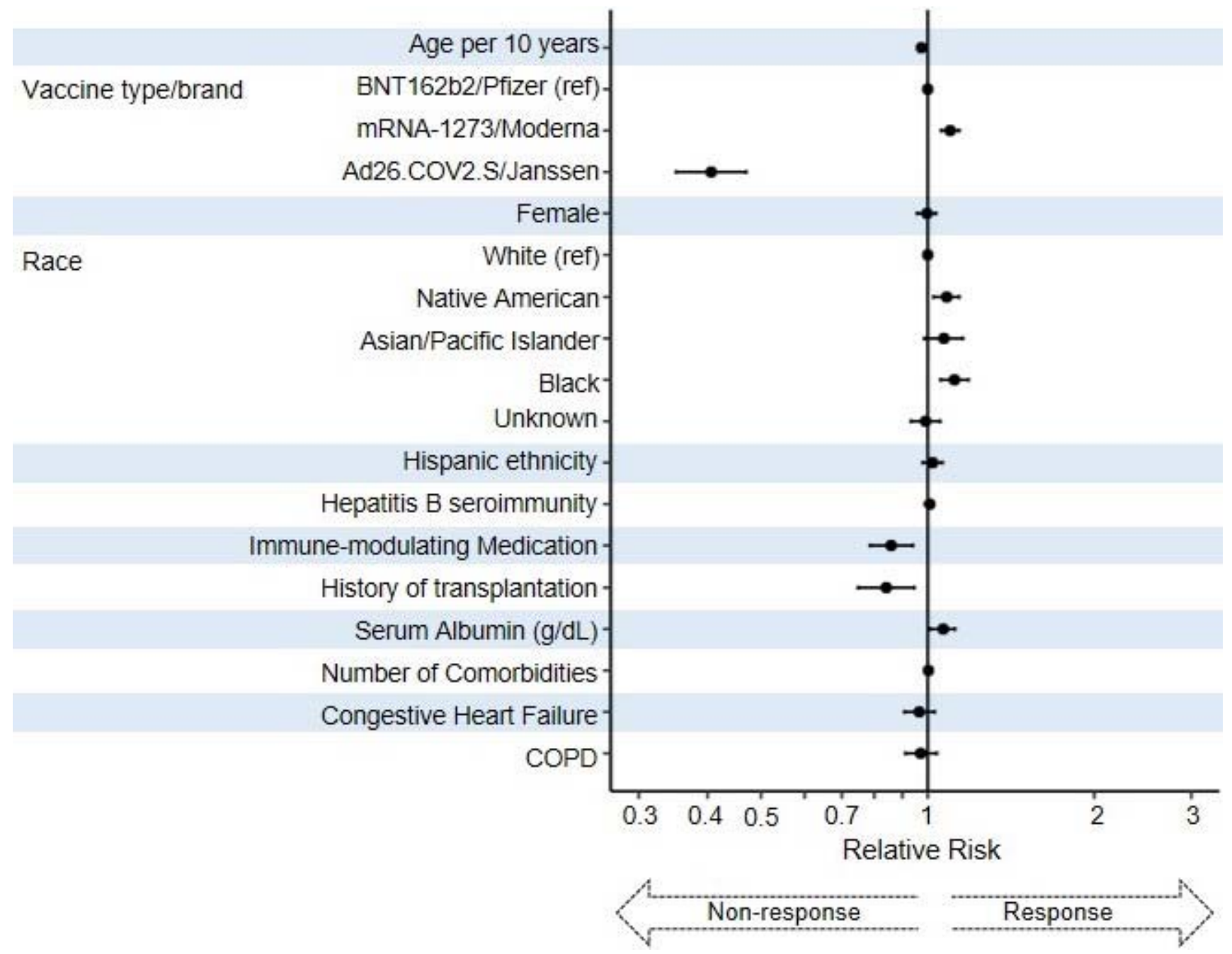

Figure. Multivariable regression of clinical characteristics predicting SARS-CoV-2 vaccine response

SARS-CoV-2 vaccine response defined as immunoglobulin-G spike antibodies (SAb-lgG) against the receptor-binding domain of the $\mathrm{S} 1$ subunit of SARS-CoV-2 spike antigen titer $\geq 1 \mathrm{U} / \mathrm{L}$ measured 14-74 days after completion of a vaccine series

Hepatitis B seroimmunity defined as hepatitis B surface antibody $\geq 10 \mathrm{mlU} / \mathrm{mL}$

COPD Chronic Obstructive Pulmonary Disease 